\title{
Performance of Okra (Abelmoschus esculentus L. Moench) under Different Spatial Arrangements of Melia composita Based Agroforestry System
}

\author{
J.B. Bhusara, M.J. Dobriyal", N.S. Thakur, R.P. Gunaga and M.B. Tandel \\ Department of Silviculture and Agroforestry, College of Forestry, Navsari Agricultural \\ University, Navsari 396450 Gujarat, India \\ *Corresponding author
}

\begin{tabular}{|l|}
\hline Ke y w o r d s \\
Agroforestry, Okra, \\
Abelmoschus esculentus, \\
Melia composita, Malabar \\
Neem, Spatial
\end{tabular}

\section{Introduction}

Agroforestry is a dynamic, ecologically based natural resource management system, through which the integration of trees/woody perennials in farm and rangelands, diversifies and sustains production for increased social, economic and environmental benefits (Leakey, 1996; Bhusara et al., 2017a and b;
Okra (Abelmoschus esculentus L. Moench) is an important vegetable crop and Melia composita (Malabar Neem or Nimabaro) is emerging industrial agroforestry plantations in southern Gujarat. To maximize the land utilization an agroforestry trial was laid to investigate the performance of okra varieties under different spatial arrangements of 2 year old Melia composita plantation with three spacing of $S_{1}(2 \times 2 \mathrm{~m}), \mathrm{S}_{2}(2 \times 3 \mathrm{~m})$ and $\mathrm{S}_{3}(4 \times 2$ m) while $S_{0}$ as open field at College of Forestry, ACHF, Navsari Agricultural University, Navsari, Gujarat, India, during winter season of 2015-16 and 2016-17. Okra crop (OV 1 GAO-5 and $\mathrm{OV}_{2}$ - GJO-3) was intercropped with $M$. composita reported lower growth parameters as well lower yield as compared to open condition. The results of pooled analysis of two years shown that treatment $\mathrm{T}_{2}-\mathrm{S}_{0} \mathrm{OV}_{2}$ recorded maximum plant height$106.38 \mathrm{~cm}$, number of branches per plants- 4.68, number of leaves per plants- 36.68 , number of flower per plant -26.07 , average number of fruits per plant- 22.75, fresh fruit yield per plant- $302.71 \mathrm{~g}$ and per hectare- 13.62 tonnes in open condition followed by $\mathrm{OV}_{1}$ variety. Similarly in intercropping the growth and yield attributes of Okra were minimum height $-85.74 \mathrm{~cm}$, number of branches per plants - 3.59, number $\mathrm{f}$ leaves per plant- 25.06, number of flower per plant - 13.27, average number of pod per plant - 16.02 , fresh fruit yield per plant- $268.89 \mathrm{~g}$ and per hectare- 12.10 tonnes were reported in $\mathrm{T}_{3}$ $\left(\mathrm{S}_{1} \mathrm{OV}_{1}\right)$ i.e. in $2 \times 2 \mathrm{~m}$ closer spacing while under wider spacing of $\mathrm{S}_{2}$ and $\mathrm{S}_{3}$ okra responded significantly better respectively. Hence wider spacing of $S_{3}(4 \times 2 \mathrm{~m})$ can be suggested for intercropping under $M$. composita plantations in initial 2-4 years. 
order to utilize the interspaces in early stages in closer spacing and wider spacing even in later stages of plantation development the selection of the crops for intercropping is important (Verma et al., 2010; Thakur et al., 2011; Thakur and Verma, 2012; Thakur et al., 2014; Jilariya et al., 2017; Thakur et al., 2018).

Okra or lady finger (Abelmoschus esculentus L. Moench) belongs to Malvaceae family is an economically important vegetable crop grown in tropical and sub-tropical parts of the world. In the world, India ranks second in the production of vegetables, next to China with 403.2 lakh tonnes from 43.1 lakh hectares of land. Okra is popular in India because of easy cultivation, dependable yield and adaptability to varying moisture conditions. It has tremendous export potential as fresh vegetable.

Okra is one of the important vegetable crops of Gujarat, covering an area of 41,500 hectares with a production of 3,65,200 tonnes with average productivity of 8.82 tonnes ha $^{-1}$ reg. okra requires warm and moist season for higher yield. Melia composita Wild. (Malabar Neem or Nimabaro) belongs to the meliaceae family is an indigenous species which also distributed to South East Asia and Australia. $M$. composita is very large and fast growing deciduous tree with a straight cylindrical trunk attaining a height of 20-25 m with a spreading crown and a straight bole of $9 \mathrm{~m}$ length and $1.2-1.5 \mathrm{~m}$ girth. It is a short rotation multipurpose tree species which yield useful termite proof timber and also used for packing cases, cigar boxes, tea box, ceiling planks, agricultural implements, pencils, match boxes and splints musical instruments $M$. composita is being advocated as amenable tree species for agroforestry without any deleterious effect on under-storye crops (Kumar et al., 2017a; Thakur et al., 2017a,b,c, Parmar et al., 2018). Okra is an important vegetable crop and $M$. composita is emerging industrial agroforestry plantations in southern Gujarat. Recently in agricultural land a large scale plantations are done for the pulpwood and paper industry which necessitated the intercropping of agricultural crops under the $M$. composita. Many medicinal and aromatic crops have been found to perform well under $M$. dubia plantations (Jilariya et al., 2017; Mohanty et al., 2017; Thakur et al., 2018) and other vegetable and pulse crops are yet be examined. To maximize the land utilization an agroforestry trial was laid to investigate the performance of okra varieties under different spatial arrangements of 2 year old $M$. composita plantation.

\section{Materials and Methods}

Melia composita (Malabar Neem or Nimabaro) is an emerging industrial agroforestry plantations in southern Gujarat. To maximize the land utilization an agroforestry trial was laid to investigate the performance of okra varieties under different spatial arrangements of 2 year old $M$. composita plantation at College of Forestry, ACHF, Navsari Agricultural University, Navsari, Gujarat, India, during winter season of 2015-16 and 2016-17. The experiments designed for intercropping of two Okra varieties $\left(\mathrm{OV}_{1^{-}}\right.$GAO-5 and $\left.\mathrm{OV}_{2}-\mathrm{GJO}-3\right)$ in winter season with $M$. composita, which was planted in 2014 with three spacing of $S_{1}(2 \times 2$ $\mathrm{m}), \mathrm{S}_{2}(2 \times 3 \mathrm{~m})$ and $\mathrm{S}_{3}(4 \times 2 \mathrm{~m})$ while $S_{0}$ as open field. Experiment is designed in Randomized Block Design (RBD) with eight treatments and three replications. The treatments for okra crop includes- $\mathrm{T}_{1^{-}}$

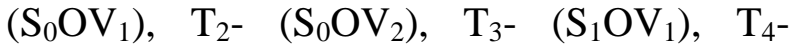
$\left(\mathrm{S}_{1} \mathrm{OV}_{2}\right), \quad \mathrm{T}_{5^{-}}\left(\mathrm{S}_{2} \mathrm{OV}_{1}\right), \quad\left(\mathrm{T}_{6^{-}}\left(\mathrm{S}_{2} \mathrm{OV}_{2}\right), \mathrm{T}_{7^{-}}\right.$ $\left(\mathrm{S}_{3} \mathrm{OV}_{1}\right)$ and $\mathrm{T}_{8^{-}}\left(\mathrm{S}_{3} \mathrm{OV}_{2}\right)$. Okra height, number of branches, number of leaves and number of flowers was recorded before final harvest by randomly selecting 5 plants in each replication and treatment. Number of fruit in 
individual selected plant was counted at every picking and finally these were added to obtain the mean number of pods per plant. Yield per plot (4 sq.m) was worked out by multiplying okra yield per plant with total number of plants in respective plots and expressed in $\mathrm{kg}$. Yield was calculated by plot value for hectare.

\section{Results and Discussion}

The data of growth and yield parameters of Okra as sole crop and under different spatial arrangements for both the year of study (201516 and 2016-17) and pooled analysis (Table 1 and 2; Fig. 1 and 2) shown that the okra maximum plant height- $106.85 \mathrm{~cm}, 105.91 \mathrm{~cm}$ and $106.38 \mathrm{~cm}$; number of branches per plants - 4.68, 4.69 and 4.68; number of leaves per plant 36.54, 36.81 and 36.68; number of flower per plant- 24.91, 27.23 and 26.06 respectively for the first year, second year and pooled analysis under treatment $\mathrm{T}_{2}-\mathrm{S}_{0} \mathrm{OV}_{2}$ in open condition as compare to other treatment combination. Similarly pooled analysis of two years data for intercropping shown the growth attributes of Okra were minimum height $85.74 \mathrm{~cm}$, number of branches per plants 3.59, number of leaves per plant- 25.06, number of flower per plant - 13.27, in treatment $\mathrm{T}_{3}\left(\mathrm{~S}_{1} \mathrm{OV}_{1}\right)$ i.e. in $2 \times 2 \mathrm{~m}$ closer spacing while under wider spacing of $S_{2}$ and $\mathrm{S}_{3} \quad$ okra responded significantly better respectively. It seems due to less availability of light under closer spacing of as $M$. composita compared to open condition resulted lower growth attributes similar trend was in past also recorded by the Rani et al., (2015) under poplar based agroforestry, Hasan et al., (2012) evaluated the performance of Indian spinach (Basella alba) and okra (Abelmoschus esculentus) in association with Lombu (Swietenia hybrid) and Rajalingam et al., (2016) in Ailanthus excelsa with vegetable, Osman et al., (2011) and beans crops, Hanif et al., (2010) in okra with litchi based agroforestry.
The yield attributes like number of fruit per plant 22.51, 22.98 and 22.75; Fresh fruit yield - 203.64g/plant, $296.78 \mathrm{~g} / \mathrm{plant}$ and $302.71 \mathrm{~g} /$ plant ; yield per hectare- 13.89 tonne/ha, 13.36 and 13.62 tonne/ha were recorded maximum in first year, second year and pooled analysis respectively with the treatment $\mathrm{T}_{2}-\mathrm{S}_{0} \mathrm{OV}_{2}$ in open condition.

Similarly in intercropping the yield attributes of Okra were lowest with average number of fruit per plant - 16.02, fresh fruit yield per plant- $268.89 \mathrm{~g}$ and per hectare- 12.10 tonnes in both year pooled analysis in $\mathrm{T}_{3}\left(\mathrm{~S}_{1} \mathrm{OV}_{1}\right)$ i.e. in $2 \times 2$ closer spacing while under wider spacing of $\mathrm{S}_{2}$ and $\mathrm{S}_{3}$ okra responded significantly better respectively. The probable reason for it might be good availability of light in open condition as compared to $M$. composita based agroforestry system, similar findings are also reported by Babu (2012) for vegetables cultivation under Eucalyptus tree rows; Singh et al., (1997) in Eucalyptus with vegetable crops, Mohammed (2012) in Poplus deltoids, Vanlalhluna et al., (2014) in maize under multipurpose tree species and Thakur $e t$ al., (2011), Bijalwan (2011) studied agricultural crop in Melia azaderach followed by Grewia optiva, and Celtis australis. Though the wider spacing of S3 (2 x4 m) can be suggested for intercropping under $M$. composita plantations in initial 2-4 years with tree pruning and other plantation management activities. The M. composita trees performed better in intercropping than in sole plantations (Fig. 3 and 4). The maximum height increment was in $\mathrm{T}_{4}-\mathrm{S}_{1} \mathrm{OV}_{1}$ as $1.20 \mathrm{~m}$ in two year while maximum DBH increment was in $\mathrm{T}_{9}-\mathrm{S}_{3} \mathrm{OV}_{2}$ as $1.78 \mathrm{~cm}$ in two year. It reflect that closer spacing with okra the height was more while with wider spacing DBH was more with intercrops. Thus intercrops favouring the growth of probably due to inputs of nutrients and irrigations provided to crops will have also utilized by the trees. 
Table.1 Vegetative growth attributes of okra under different spatial arrangements of $M$. composita and sole cropping

\begin{tabular}{|c|c|c|c|c|c|c|c|c|c|}
\hline \multirow[b]{2}{*}{ Treatments } & \multicolumn{3}{|c|}{ Height (cm) } & \multicolumn{3}{|c|}{ No. of branches/plant } & \multicolumn{3}{|c|}{ No. of leaves/plant } \\
\hline & 2015-16 & 2016-17 & Pooled & 2015-16 & 2016-17 & Pooled & 2015-16 & 2016-17 & Pooled \\
\hline$T_{1}-S_{0} O V_{1}$ & 105.48 & 104.25 & 104.86 & 4.53 & 4.51 & 4.52 & 34.98 & 35.05 & 35.02 \\
\hline $\mathrm{T}_{2}-\mathrm{S}_{0} \mathrm{OV} \mathrm{V}_{2}$ & 106.85 & 105.91 & 106.38 & 4.68 & 4.69 & 4.68 & 36.54 & 36.81 & 36.68 \\
\hline $\mathbf{T}_{3}-\mathrm{S}_{1} \mathbf{O} \mathrm{V}_{1}$ & 87.23 & 84.25 & 85.74 & 3.72 & 3.47 & 3.59 & 25.61 & 24.51 & 25.06 \\
\hline $\mathbf{T}_{4}-\mathrm{S}_{1} \mathbf{O V} \mathrm{V}_{2}$ & 88.60 & 85.91 & 87.26 & 3.85 & 3.63 & 3.74 & 27.17 & 26.27 & 26.72 \\
\hline $\mathrm{T}_{5}-\mathrm{S}_{2} \mathrm{OV}_{1}$ & 89.98 & 87.58 & 88.78 & 3.98 & 3.80 & 3.89 & 28.73 & 28.02 & 28.38 \\
\hline $\mathrm{T}_{6}-\mathrm{S}_{2} \mathrm{OV}_{2}$ & 91.35 & 89.25 & 90.30 & 4.11 & 3.97 & 4.04 & 30.29 & 29.78 & 30.04 \\
\hline $\mathbf{T}_{7}-\mathrm{S}_{3} \mathbf{O V} \mathrm{V}_{1}$ & 92.73 & 90.91 & 91.82 & 4.25 & 4.15 & 4.20 & 31.86 & 31.54 & 31.70 \\
\hline $\mathrm{T}_{8}-\mathrm{S}_{3} \mathrm{OV} \mathrm{V}_{2}$ & 94.10 & 92.58 & 93.34 & 4.38 & 4.32 & 4.35 & 33.42 & 33.30 & 33.36 \\
\hline S. Em \pm & 1.29 & 1.26 & 0.90 & 0.20 & 0.26 & 0.16 & 1.58 & 1.75 & 1.18 \\
\hline C.D. at $5 \%$ & 3.92 & 3.83 & 2.36 & 0.61 & 0.77 & 0.47 & 4.80 & 5.30 & 3.40 \\
\hline S.Em $\pm($ Y X T $)$ & - & - & 1.28 & - & - & 0.23 & - & - & 1.66 \\
\hline CD at $5 \%($ Y X T $)$ & - & - & NS & - & - & NS & - & - & NS \\
\hline CV \% & 9.37 & 9.36 & 9.37 & 8.26 & 10.86 & 9.61 & 8.82 & 9.88 & 9.33 \\
\hline
\end{tabular}


Table.2 Reproductive growth attributes of okra under varying spatial arrangements of $M$. composita and sole cropping

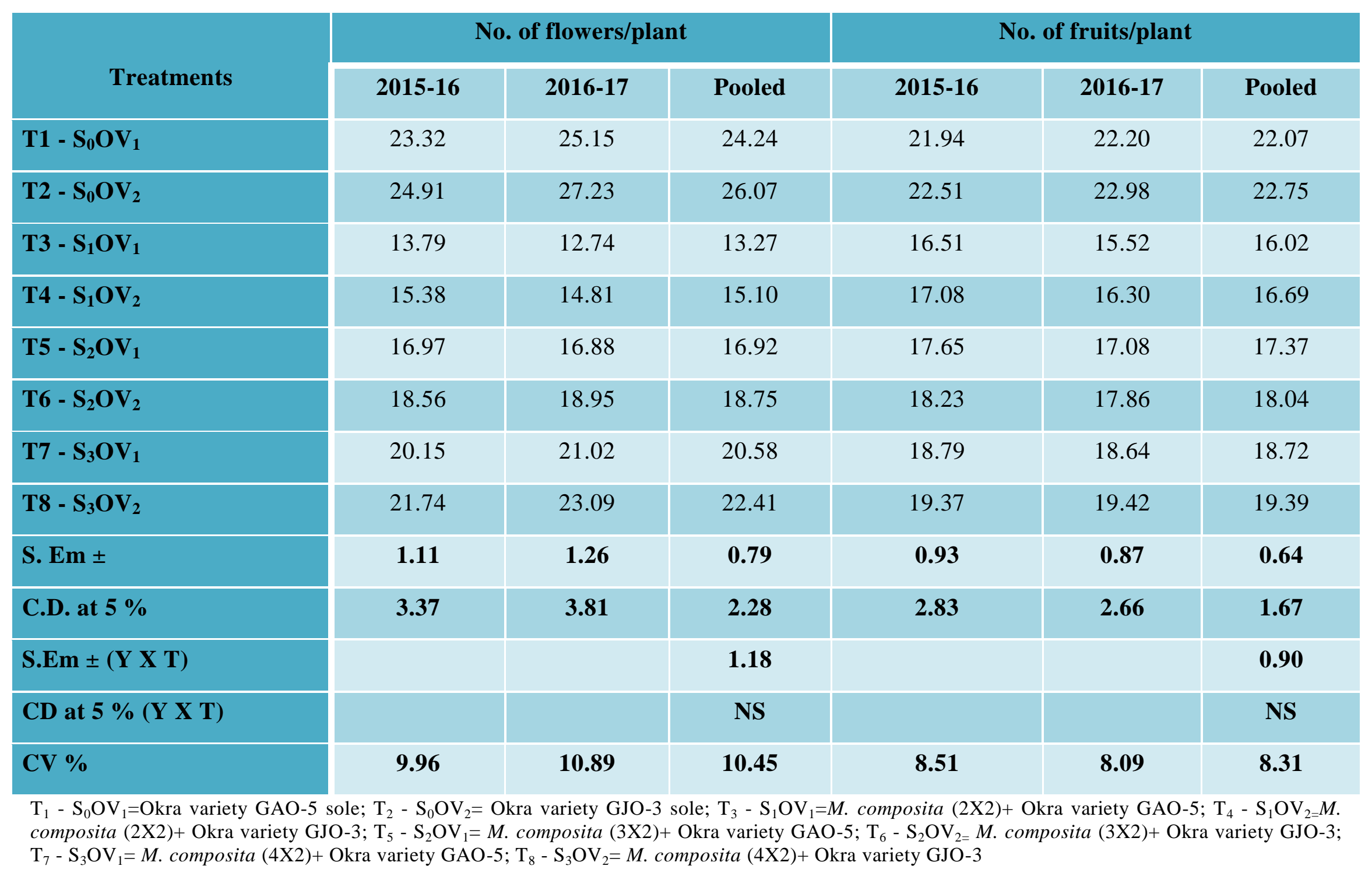


Table.3 Yield attributes of okra under different spatial arrangements of $M$. composita and sole cropping systems

\begin{tabular}{|c|c|c|c|c|c|c|c|c|c|}
\hline Treatments & \multicolumn{3}{|c|}{ Fresh fruit yield (g/plant) } & \multicolumn{3}{|c|}{ Fresh fruit yield (Kg/plot) } & \multicolumn{3}{|c|}{ Fresh fruit yield (tonne/ha) } \\
\hline $\mathrm{T} 2-\mathrm{S}_{0} \mathrm{OV}_{2}$ & 308.64 & 296.78 & 302.71 & 5.56 & 5.34 & 5.45 & 13.89 & 13.36 & 13.62 \\
\hline $\mathrm{T} 4-\mathrm{S}_{1} \mathrm{OV} \mathrm{V}_{2}$ & 276.83 & 270.61 & 273.72 & 4.98 & 4.87 & 4.93 & 12.46 & 12.18 & 12.32 \\
\hline $\mathrm{T} 5-\mathrm{S}_{2} \mathrm{OV} \mathrm{V}_{1}$ & 282.13 & 274.97 & 278.55 & 5.08 & 4.95 & 5.01 & 12.70 & 12.37 & 12.53 \\
\hline $\mathrm{T} 6-\mathrm{S}_{2} \mathrm{OV}_{2}$ & 287.44 & 279.34 & 283.39 & 5.17 & 5.03 & 5.10 & 12.93 & 12.57 & 12.75 \\
\hline $\mathrm{T} 7-\mathrm{S}_{3} \mathrm{OV}_{1}$ & 292.74 & 283.70 & 288.22 & 5.27 & 5.11 & 5.19 & 13.17 & 12.77 & 12.97 \\
\hline C.D. at $5 \%$ & 15.79 & 14.51 & 10.19 & 0.28 & 0.26 & 0.17 & 0.71 & 0.65 & 0.41 \\
\hline $\mathrm{S} . \mathrm{Em} \pm(\mathbf{Y} \mathbf{X} \mathbf{T})$ & & & 4.99 & & & 0.09 & & & 0.22 \\
\hline CD at $5 \%(\mathbf{Y}$ X T $)$ & & & NS & & & NS & & & NS \\
\hline $\mathrm{CV} \%$ & 3.11 & 2.94 & 3.03 & 3.11 & 2.94 & 3.02 & 3.11 & 2.94 & 3.02 \\
\hline
\end{tabular}

$\mathrm{T}_{1}-\mathrm{S}_{0} \mathrm{OV}_{1}=$ Okra variety GAO-5 sole; $\mathrm{T}_{2}-\mathrm{S}_{0} \mathrm{OV}_{2}=$ Okra variety GJO-3 sole; $\mathrm{T}_{3}-\mathrm{S}_{1} \mathrm{OV}_{1}=M$. composita $(2 \mathrm{X} 2)+\mathrm{Okra}$ variety $\mathrm{GAO}_{-5} ; \mathrm{T}_{4}-\mathrm{S}_{1} \mathrm{OV} \mathrm{V}_{2=} M$. composita (2X2)+ Okra variety GJO-3; $\mathrm{T}_{5}-\mathrm{S}_{2} \mathrm{OV}_{1}=$ M. composita $(3 \mathrm{X} 2)+$ Okra variety GAO-5; $\mathrm{T}_{6}-\mathrm{S}_{2} \mathrm{OV}_{2=}$ M. composita (3X2)+ Okra variety GJO-3; $\mathrm{T}_{7}-\mathrm{S}_{3} \mathrm{OV}_{1}=$ M. composita $(4 \mathrm{X} 2)+$ Okra variety GAO-5; $\mathrm{T}_{8}-\mathrm{S}_{3} \mathrm{OV}_{2}=$ M. composita $(4 \mathrm{X} 2)+$ Okra variety GJO-3

(Plot Size: 4 sq.m) 
Fig.1 Growth attributes of Okra under different spatial arrangements of $M$. composita and sole cropping systems (Flowers, Branches, Fruits)

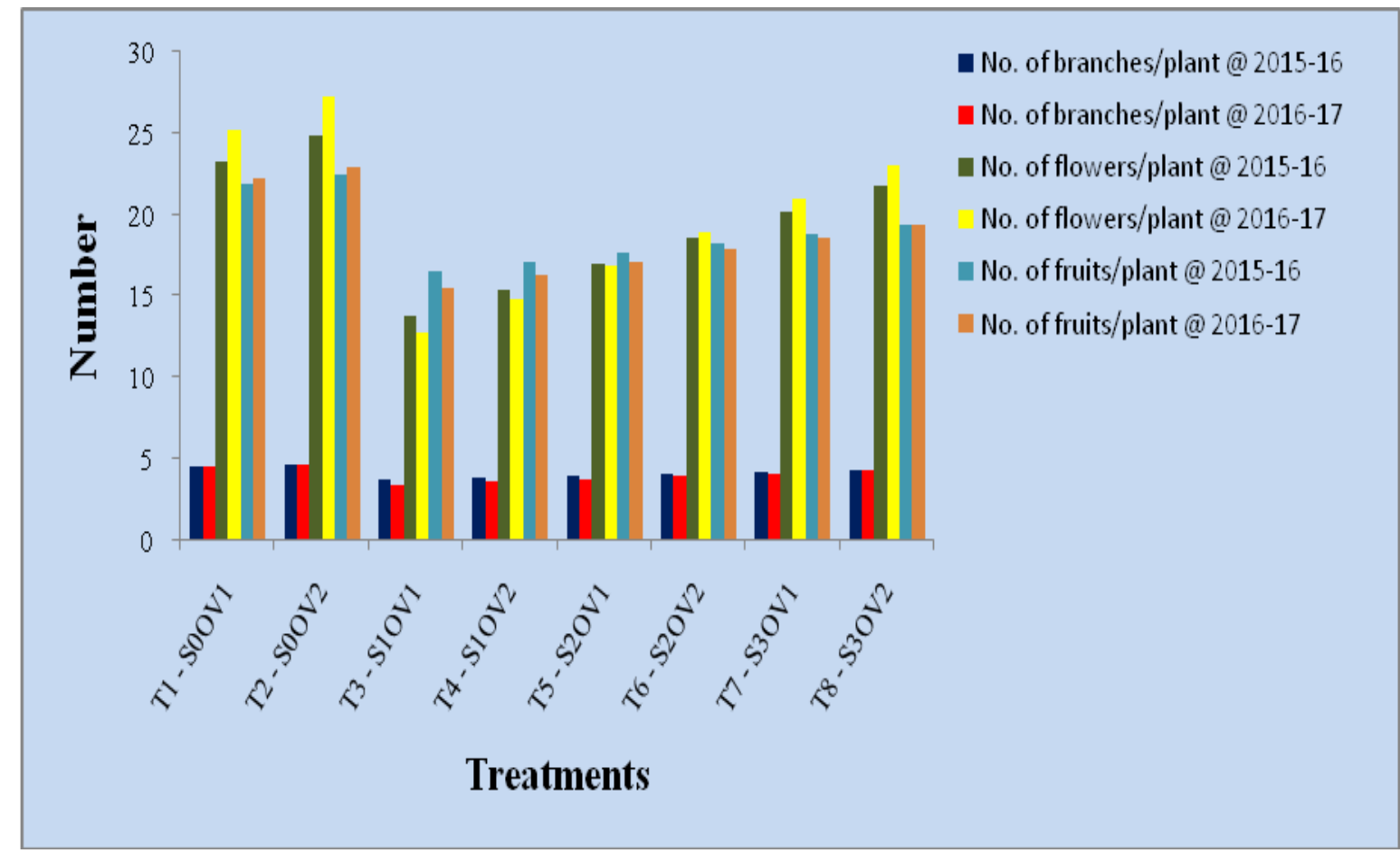

Fig.2 Yield (per plant and per hectare) attributes of okra under different spatial arrangements of M. composita and sole cropping systems

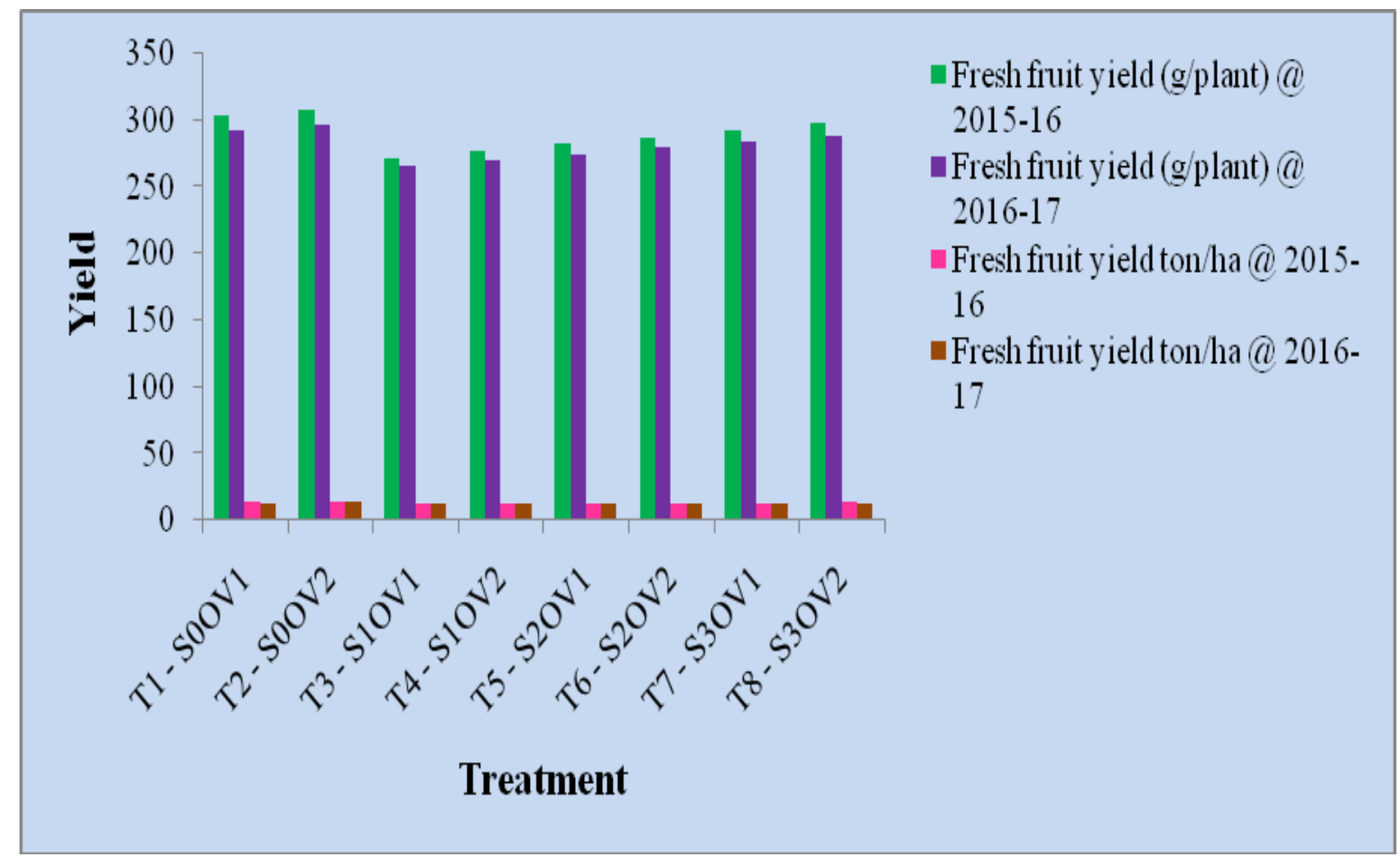


Fig.3 Growth attributes (Height) of $M$. composita in different spatial arrangement under sole plantation and with okra intercrop

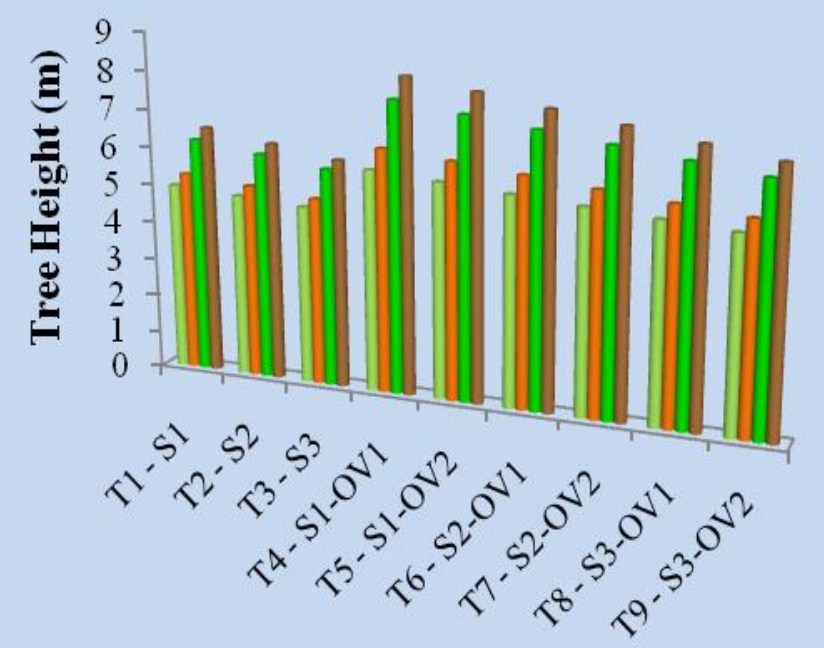

At Okra sowing@ 2015-16

-At Okra harvesting@2015-16

चAt Okra sowing@2016-17

- At Okra harvesting@2016-17

Treatment

Fig.4 Growth attributes (DBH) of $M$. composita in different spatial arrangement under sole plantation and with okra intercrop

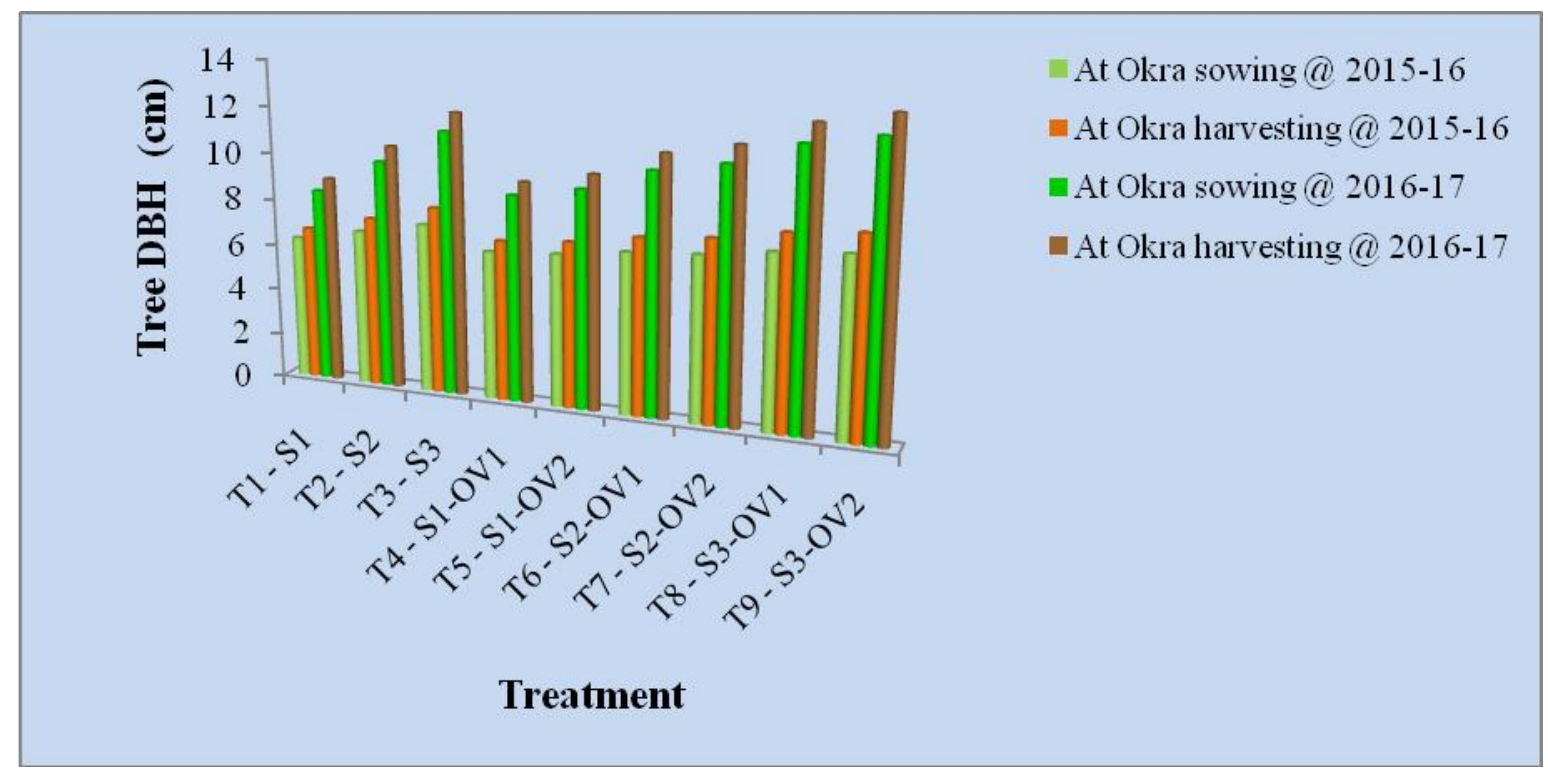

Intercropping of vegetable with fast growing trees provide maximum returns to the farmers as compared to sole plantation or sole cropping. The interaction of trees and crops can be utilized for maximum gain by technological interventions and good agricultural practices. In present study the intercropping of okra varieties with Melia composita plantations in different spacing were found highest under sole cropping compared to intercropping. However, contrary the growth and yield parameters of 
M. composita were found maximum with intercrops than sole plantation irrespective of spatial arrangement.

The average maximum pod yield of okra reported in $\mathrm{T}_{2}$-(sole cropping with variety GJO-3) as $302 \mathrm{~g} /$ plant and 13.62 tonnes/ ha while in intercropping maximum yield was recorded with $\mathrm{T}_{8^{-}}$(variety $\mathrm{GJO}-3$ with $M$. composita at $4 \times 2 \mathrm{~m}$ spacing) as $293.05 \mathrm{~g} /$ plant and 13.19 tonnes/ ha which shows marginal reduction of 0.43 tonnes/ ha in yield (Table 3).

Hence wider spacing of $(4 \times 2 \mathrm{~m})$ can be suggested for intercropping under $M$. composita plantations in initial 2-4 years.

\section{Acknowledgement}

Authors are thankful to the Hon'ble Vice Chancellor of Navsari Agricultural University, Navsari, Gujarat for providing the all kind of facilities and inputs to conduct this study in Forestry college farm of the University.

\section{References}

Babu, A. M. (2012). Boundary plantation of eucalyptus and its effect on chilli and sweet gourd. M.sc. Thesis, Dept. Of Agroforestry, BAU, Mymen singh, Bangladesh.

Bijalwan, A. (2011). Assessment of Crop yield under indigenous agroforestry system in Garhwal Himalayan region of India. Indian journal of Agroforestry. 2(2):123-127

Bhusara, J. B., Thakur, N. S., and Hegde, H. T. 2016a. Bio-economic appraisal of traditional agroforestry systems prevalent in Valsad district Gujarat. Journal of Tree Sciences, 35(2): 7-14. DOI: $105958 / 2455$

7129.2016.00002.9.
Bhusara, J. B., Thakur, N. S., and Hegde, H. T. 2016b. Biological yield and carbon sequestration in prominent traditional agroforestry systems in Valsad District, Gujarat, India. Indian Journal of Ecology, 43 (1): 318-320.

Hanif, M. A., Amin, M. H. A., Bari, M. S., Ali, M. S. and Uddin, M. N. (2010). Performance of okra under litchi based agroforestry system. J. Agrofor. Environ. 4 (2): 137-139.

Hasan, M. R., Akter, A., Alam, Z. and Wadud, M. A. (2012) Indian spinach and Okra cultivation along with Swietenia hybrida tree as agroforestry practices. J. Agrofor. Environ, 6 (2): 119-124.

Jilariya, D. J., Thakur, N. S., and Gunaga, R. P. (2017). Quantitative and qualitative attributes of Aloe vera Linn. grown under Melia composita Willd. and sole cropping systems. Indian Journal of Ecology, 44 (Special Issue-5): 451455.

Kumar, D., Thakur, N. S., and Gunaga, R. P. (2017a). Effects of leaf aqueous extract and leaf litter of Melia composita Willd. on black gram [Vigna mungo (L.) Hepper]. Allelopathy Journal, 41(1): 127-140.

Kumar, M., Thakur, N. S., Bardhan, Kirti., and Bhusara, J. B. (2017b). Effect of teak (Tectona grandis L)-Ocimum spp-based silvi-medicinal systems on growth and physiological parameters of Ocimum spp. International Journal of Farm Sciences, 7(1): 8-14.

Leakey, R.R.B. (1996) Definition of agroforestry. Agroforestry Today, 8, 5-7.

Mohanty, S., Thakur, N. S., Gunaga, R. P., Dobriyal, M. J., and Desai, B. S. (2017). Value addition in Cymbopogon spp. to enhance the financial flows from Cymbopogon spp.-Melia dubia Cav. based 
silvimedicinal and sole cropping systems. Indian Journal of Ecology, 44 Special Issue (6): 812-816.

Osman, A. N., Raebild, A., Christiansen, J. L., and Bayala, J. (2011). Performance of cowpea (Vigna unguiculata) and pearl millet (Pennisetum glaucum) intercropped under Parkia biglobosa in an agroforestry system. burkina faso. Afr. J. Agric. Res, 6(4): 882- 891.

Panchal, J. S., Thakur, N. S., Jha, S. K., and Kumar, V. (2017). Productivity and carbon sequestration under prevalent agroforestry systems in Navsari District, Gujarat, India. International Journal of Current Microbiology and Applied Sciences 6(9): 3405-3422. doi: https://doi.org/10.20546/ijcmas. 2017.609.419

Parmar, A. G., Thakur, N. S., and Gunaga, R. P. (2018). Melia dubia Cav. leaf litter allelochemicals have ephemeral allelopathic proclivity. Agroforestry Systems. 1-14 https://doi.org/10.1007/ s10457-018-0243-5

Rajalingam, G. V., Divya, M. P., Prabaharan, C. and Parthiban, K. T. (2016). Performance of vegetable crops under Ailanthus excelsa based agroforestry system. Indian J. of Agroforestry, 18: 16-20 (2016).

Rani, S., Rajasekaran, A., Benbi, D. K., and Chauhan, S. K. (2015). Cost benefits analysis and yield performance of agricultural crops under poplar and fruit crop in north western zone of
Punjab, India. International journal of scientific research, 4 (6): 2277 - 8179.

Singh, B., Singh, V., Singh, R. P. and Srivastava, B. K. (1997). Effect of young Eucalyptus trees on the growth, yield and quality of vegetable intercrops. Indian J. Hort., 54 (4): 320-326.

Thakur, N. S., Verma, K. S., and Rana, R. C. (2011). Effect of tree-crop combinations and nitrogen levels on velvet bean (Mucuna pruriens L.) grown in agrihorti-silvi-pasture system of agroforestry in mid Himalayan region. J. of Non-timber Forest Products, 18 (4): 303-312.

Vanlalhluna, C.P., Sahoo, K. and Singh L. (2014). Growth and yield of agricultural crops intercropped under three multipurpose tree (MPTs) in Mizoram, North-East, India. Paper presented in World Agroforestry Congress, 12-14 February-, New Delhi.

Verma, K. S., Thakur, N. S., and Rana, R. C. (2010). Effect of tree crop combinations and nitrogen levels on herbage yield of sacred basil (Ocimum sanctum L.) grown in agri-horti-silvipasture system in mid hill Himalayas. Indian Journal of Agroforestry, 12(1): 71-76.

\section{How to cite this article:}

Bhusara J. B., M. J. Dobriyal, N. S. Thakur, R. P. Gunaga and Tandel M. B. 2018. Performance of Okra (Abelmoschus esculentus L. Moench) under Different Spatial Arrangements of Melia composita Based Agroforestry System. Int.J.Curr.Microbiol.App.Sci. 7(05): 3533-3542. doi: https://doi.org/10.20546/ijcmas.2018.705.408 